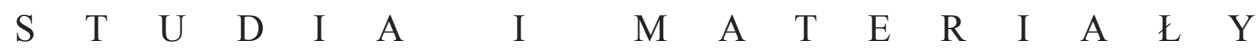

Marek Jerzy Minakowski

ORCID: https://orcid.org/0000-0001-5677-9277

Dr Minakowski Publikacje Elektroniczne

email:mj@minakowski.pl

\title{
House of Networks: the Polish-Lithuanian Senate (1569-1795) as Parliamentary Representation of the National Social Network (of Women?)
}

\section{Izba Sieci. Polsko-litewski senat (1569-1795) jako reprezentacja parlamentarna ogólnokrajowej (kobiecej?) sieci społecznej}

\begin{abstract}
The Polish-Lithuanian Parliament of 15691795 consisted of three houses: The King, Senate and House of Representatives. The King and Representatives were elected in general election. The members of the Senate were arbitrarily appointed by the King for a lifetime tenure. There is an extensive literature on the forming of the Polish-Lithuanian elite of power in the 16 th-18th centuries. The article proves that the literature missed several vital aspects of the issue. Even if the appointments to the Senate were arbitrary, they reflected the real position of politicians in the country's social network, as if the social network were the real ruling power
\end{abstract}

\begin{abstract}
Abstrakt
Polsko-litewski parlament (1569-1795) składał się z trzech izb: króla, senatu i izby poselskiej. Król i posłowie byli wybierani w wyborach powszechnych. Członkowie senatu byli nominowani dożywotnio przez króla. Mamy obszerną literaturę o kształtowaniu się polsko-litewskiej elity władzy w wiekach XVI-XVIII. Artykuł dowodzi, że ta literatura pomija kilka istotnych aspektów tematu. Nawet jeżeli nominacje senatorskie były arbitralne, odpowiadały one rzeczywistej pozycji polityków w ogólnokrajowej sieci społecznej, tak jakby sieć społeczna była jedną z realnych władz kraju, wpływając na decyzje królewskie. Zaś status polityków był bardziej
\end{abstract}


in the country, influencing the King's decisions. And the status of politicians was better connected to the network position of their mothers and wives than to their surname and male line.

\section{Keywords}

mass genealogy, historical social networks, comparative history, parliament, democracy związany z pozycją ich matek i żon niż $\mathrm{z}$ ich nazwiskiem i linią męską.

\section{Słowa kluczowe}

genealogia masowa, historyczne sieci społeczne, historia porównawcza, parlament, demokracja

\section{Introduction $^{1}$}

In the last period of the communist regime in Poland, there was great interest among Polish historians in the formation of the elites of power in Polish-Lithuanian history. Politics at that time was extremely difficult to access and discussion of recent times hampered by censure, so would-be politicians studied history instead. ${ }^{2}$ Dozens of prominent historians were involved in preparing lists of officials in every land of the former Polish-Lithuanian union, which resulted in a series of books under the common title "Officials of the old Polish-Lithuanian Commonwealth." The system of power in this great country, up to 990,000 square kilometers at its peak, ${ }^{3}$ was distributed, to some extent, in a similar way to today's European Union: with weak central power and a stress on subsidiarity. The central government was also very weak because it had little to govern, as royal land (agriculture being the base of the country's economy, land was its main asset) was usually leased to private persons, who had only to pay one fourth of the income. The army was also private to some extent, as it was (at least in theory) based on

${ }^{1}$ This paper was first given in December 2018 at the bi-monthly gathering of Zespół Demografii Historycznej KND PAN. The findings presented here, although based on a technical analysis of demographic (genealogical) data, reach further to the fields of general history, social sciences and comparative political studies. Therefore, the author intentionally decided to choose a form and language that would be suitable for a general audience in the fields of these disciplines worldwide.

${ }^{2}$ Students of history in the 1970s and 1980s included such figures as Donald Tusk (a former Polish Prime Minister and President of the European Union), Mateusz Morawiecki (the current Polish PM), Bronisław Komorowski (a former Polish President), Grzegorz Schetyna (the current leader of the opposition in Poland) and Ryszard Czarnecki (a former vice-president of the European Parliament, 2014-2018). Cf. their biographies, passim.

${ }^{3}$ Andrzej Jezierski and Andrzej Wyczański, eds., Historia Polski w liczbach. I. Państwo. Społeczeństwo (Warszawa: Zakład Wydawnictw Statystycznych, 2003), 21. 
nobles, whose ancestors had received hereditary ownership of land in the Middle Ages in return for hereditary military service. ${ }^{4}$ Education and social security were in the hands of the non-government sector (mostly religious institutions, providing services for different Christian denominations and Jews, separately).

Offices were distributed in a similar way to the system of power; as a result, they were separately described for every land or province. This also applied to lists of senators. Senators from Greater Poland, ${ }^{5}$ central Poland, ${ }^{6}$ present Ukraine, ${ }^{7}$ Lesser Poland,${ }^{8}$ Livonia (the present Latvia), ${ }^{9}$ Royal Prussia (the present Pomorze), ${ }^{10}$ Podlasie ${ }^{11}$ - all were covered in the original series by the Biblioteka Kórnicka. The Grand Duchy of Lithuania, which is presently divided into

${ }^{4}$ Even if the basic part of the army was professional (financed by taxes levied by parliament), every citizen (nobleman) was entitled to carry his own sword on a daily basis; the sword was the main attribute of the citizen and a symbol of his voting rights.

${ }^{5}$ Maria Bielińska, Antoni Gąsiorowski, and Jerzy Łojko, Urzędnicy Dawnej Rzeczypospolitej. Spisy. I/1: Urzędnicy Wielkopolscy XII-XV Wieku (Wrocław: Ossolineum, 1985); Adam Bieniaszewski, Urzędnicy Dawnej Rzeczypospolitej. Spisy. I/2: Urzędnicy Wielkopolscy XVI-XVIII Wieku (Wrocław: Ossolineum, 1987).

${ }^{6}$ Janusz Bieniak and Alicja Szymczakowa, Urzędnicy Dawnej Rzeczypospolitej. Spisy. II/1: Urzędnicy Łęczyccy, Sieradzcy i Wieluńscy XIII-XV Wieku (Wrocław: Ossolineum, 1985); Edward Opaliński and Hanka Żerek-Kleszcz, Urzędnicy Dawnej Rzeczypospolitej. Spisy. II/2: Urzędnicy Województw Łęczyckiego i Sieradzkiego XVI-XVIII Wieku (Kórnik: Biblioteka Kórnicka, 1993).

${ }^{7}$ Kazimierz Przyboś, Urzędnicy Dawnej Rzeczypospolitej. Spisy. III/1: Urzędnicy Województwa Ruskiego XIV-XVIII Wieku (Wrocław: Ossolineum, 1987); Henryk Gmiterek and Ryszard Szczygieł, Urzędnicy Dawnej Rzeczypospolitej. Spisy. III/2: Urzędnicy Województwa Betskiego i Ziemi Chetmskiej XIV-XVIII Wieku (Kórnik: Biblioteka Kórnicka, 1992); Eugeniusz Janas, Witold Kłaczewski, and Anna Sochacka, Urzędnicy Dawnej Rzeczypospolitej. Spisy. III/3: Urzędnicy Podolscy XIV-XVIII Wieku (Kórnik: Biblioteka Kórnicka, 1998); Eugeniusz Janas and Witold Kłaczewski, Urzędnicy Dawnej Rzeczypospolitej. Spisy. III/4: Urzędnicy Województw Kijowskiego i Czernihowskiego XV-XVIII Wieku (Kórnik: Biblioteka Kórnicka, 2002); Marian Wolski, Urzędnicy Dawnej Rzeczypospolitej. Spisy. III/5: Urzędnicy Wołyńscy XIV-XVIII Wieku (Kórnik: Biblioteka Kórnicka, 2007).

${ }^{8}$ Janusz Kurtyka et al., Urzędnicy Dawnej Rzeczypospolitej. Spisy. IV/1: Urzędnicy Małopolscy XII-XV Wieku (Wrocław: Ossolineum, 1990); Janusz Bieniak and Sobiesław Szybkowski, Urzędnicy Dawnej Rzeczypospolitej. Spisy. VI/2: Urzędnicy Kujawscy i Dobrzyńscy XII-XV Wie$k u$ (Kórnik: Biblioteka Kórnicka, 2014); Krzysztof Chłapowski and Alicja Falniowska-Gradowska, Urzędnicy Dawnej Rzeczypospolitej. Spisy. IV/3: Urzędnicy Województwa Sandomierskiego XVI-XVIII Wieku (Kórnik: Biblioteka Kórnicka, 1993); Witold Kłaczewski and Wacław Urban, Urzędnicy Dawnej Rzeczypospolitej. Spisy. IV/4: Urzędnicy Województwa Lubelskiego XVI-XVIII Wieku (Kórnik: Biblioteka Kórnicka, 1991).

${ }^{9}$ Krzysztof Mikulski and Andrzej Rachuba, Urzędnicy Dawnej Rzeczypospolitej. Spisy. IX: Urzędnicy Inflanccy XVI-XVIII Wieku (Kórnik: Biblioteka Kórnicka, 1994).

${ }^{10}$ Krzysztof Mikulski, Urzędnicy Dawnej Rzeczypospolitej. Spisy. V/2: Urzędnicy Prus Królewskich XV-XVIII Wieku (Wrocław: Ossolineum, 1990); Krzysztof Mikulski and Wojciech Stanek, Urzędnicy Dawnej Rzeczypospolitej. Spisy. VI/2: Urzędnicy Kujawscy i Dobrzyńscy XVIXVIII Wieku (Kórnik: Biblioteka Kórnicka, 1990); Bieniak and Szybkowski, Urzędnicy Dawnej Rzeczypospolitej. Spisy. VI/2: Urzędnicy Kujawscy i Dobrzyńscy XII-XV Wieku.

${ }^{11}$ Ewa Dubas-Urwanowicz et al., Urzędnicy Dawnej Rzeczypospolitej. Spisy. VIII: Urzędnicy Podlascy XIV-XVIII Wieku (Kórnik: Biblioteka Kórnicka, 1994). 
Lithuania, Belarus and, partially, the Russian Federation, is now published by the DiG. ${ }^{12}$ Mazowsze was only partly covered..$^{13}$ The remaining can be found in older publications. ${ }^{14}$

The work (and the entire atmosphere it was part of) led to the creation of many detailed books, which analyzed the power elite in the Polish-Lithuanian Commonwealth at various times and areas. Especially important were the books describing the senatorial elite in the early 17 th century, ${ }^{15}$ late 17 th century ${ }^{16}$ and the first two thirds of the 18th century. ${ }^{17}$ An insightful bibliography and theoretical analysis was provided in English by Paul D. McLean. ${ }^{18}$

All these analyses were based on two similar assumptions:

a) senatorial seats are analyzed not in their proper order in the House of Senate, but in broad categories: usually as palatines and castellans (often only so-called "greater castellans," sitting in the first row in the House of Senate), sometimes ministers; the actual order of seats in the Senate seems to be ignored;

${ }^{12}$ Henryk Lulewicz, Andrzej Rachuba, and Przemysław P. Romaniuk, Urzędnicy Wielkiego Księstwa Litewskiego I: Województwo Wileńskie (Warszawa: DiG, 2004); Henryk Lulewicz et al., Urzędnicy Wielkiego Księstwa Litewskiego II: Województwo Trockie (Warszawa: DiG, 2006); Henryk Lulewicz et al., Urzędnicy Wielkiego Księstwa Litewskiego III: Księstwo Żmudzkie (Warszawa: DiG, 2015); Henryk Lulewicz, Andrzej Rachuba, and Przemysław P. Romaniuk, Urzędnicy Wielkiego Księstwa Litewskiego IV: Ziema Smoleńska i Województwo Smoleńskie (Warszawa: DiG, 2003).

${ }^{13}$ Andrzej Haratym and Mirosław Nagielski, "Urzędnicy Województwa Rawskiego," in Lauda Ziemi Rawskiej i Województwa Rawskiego 1583-1793, ed. Mirosław Nagielski (Warszawa: Neriton, 2017); Ryszard Zieliński, “Chronologia Senatorów Płockich,” Notatki Płockie Płock 1958 3, no. 8 (1958): 36-44; Ryszard Zieliński, "Senatorowie Płoccy: Dokończenie," Notatki Płockie 5, nos. 2-16 (1960): 24-30.

${ }^{14}$ Józef Wolff, Senatorowie i Dygnitarze Wielkiego Księstwa Litewskiego 1386-1795 (Kraków: Drukarnia W.L. Anczyca, 1885); Teodor Żychliński, "Biskupi, Senatorowie i Dygnitarze Polscy. I. Biskupi," Złota Księga Szlachty Polskiej XV (1893): 167-214; Teodor Żychliński, "Biskupi, Senatorowie i Dygnitarze Polscy. II. Senatorowie Świeccy. A. Kasztelanowie,” Złota Księga Szlachty Polskiej XVI (1894): 165-280; Teodor Żychliński, "Biskupi, Senatorowie i Dygnitarze Polscy. II. Senatorowie Świeccy. B. Wojewodowie,” Złota Księga Szlachty Polskiej XVII (1895): 191-249; Teodor Żychliński, "Biskupi, Senatorowie i Dygnitarze Polscy. III. Ministrowie," Ztota Księga Szlachty Polskiej XVII (1895): 249-77.

${ }^{15}$ Edward Opaliński, Elita władzy w województwach poznańskim i kaliskim za Zygmunta III (Poznań: Wydawnictwo Poznańskie, 1981); Edward Opaliński, Rodziny wielkosenatorskie w Wielkopolsce, na Kujawach i na Mazowszu za Zygmunta III: podstawy karier (Warszawa: Wydawnictwo DiG, 2007); Krzysztof Chłapowski, Elita senatorsko-dygnitarska Korony za czasów Zygmunta III i Władysława IV (Warszawa: Wydawnictwo Sejmowe, 1996).

${ }^{16}$ Stefan Ciara, Senatorowie i dygnitarze koronni w drugiej połowie XVII wieku (Wrocław: Zakład Narodowy im. Ossolińskich, 1990).

${ }^{17}$ Teresa Zielińska, Magnateria polska epoki saskiej: funkcje urzędów i królewszczyzn w procesie przeobrażeń warstwy społecznej (Wrocław: Ossolineum, 1977).

${ }^{18}$ Paul D. McLean, "Widening Access While Tightening Control: Office-Holding, Marriages, and Elite Consolidation in Early Modern Poland," Theory and Society 33, no. 2 (2004): 167-212. 
b) the members of the Senate are usually presented alphabetically, grouped by their surnames, which led to the (unproven) assumption that the real actors were dynasties (patrilineal families, sharing a common surname and coat-of-arms).

It seems that both assumptions are false, and this article is intended to prove the opposite: the political system was organized into a network, not lines; and a detailed analysis of the order of the seats in the Senate is crucial to understand this, because it reflected one's place in the social network. And the social network (not the institutions) was the real force ruling the country.

The method used here was the following: first, the formal order of seats in the Polish-Lithuanian Senate is discussed; next, it will be shown that the order was strongly correlated with the average social position of the politicians who occupied these seats (measured according to the fame of their relatives); then we will be analyzing which factors have the best explanatory power here: the position of which member of the family. This allows us to draw conclusions about what influenced royal decisions, which in turn suggests conclusions about the open and hidden powers that ruled the country (and, perhaps, other countries and international institutions, too).

\section{The Seats in the Senate}

In 1569, after 183 years of shared history, the Polish Crown and the Grand Duchy of Lithuania formed a real union. ${ }^{19}$ The acts of Union in Lublin declared that instead of two separate nations, there would be only one, led by one common parliament consisting of three houses: a king, elected in a direct election each time following the death of his predecessor (the fact that his tenure was life-long was not perceived as important: the most important for his contemporaries was the prohibition of an election vivente rege so that the current king could not influence the election of his successor). The lower house (the House of Representatives, in Polish, Izba Poselska, in Latin, Camera Nuntiorum) was to be elected via direct, personal election in regional assemblies where each constituency had the rights to elect a fixed number of representatives (usually two). ${ }^{20}$ And in the middle,

${ }^{19}$ The process of formation of the Union was recently described in detail by Robert Frost in Robert I. Frost, The Making of the Polish-Lithuanian Union, 1385-1569 (New York: Oxford University Press, 2015).

${ }^{20}$ Not everybody had voting rights during the election of the king and the representatives; the right was limited to male noblemen. But the number of noblemen was very high - at the end of 16th century, in the Polish Crown (that is, without current Lithuania and Belarus, which formed the Grand Duchy of Lithuania), it was estimated at $9.1 \%$ of the total population: Jezierski and Wyczański, Historia Polski w liczbach. I. Państwo. Spoleczeństwo, 77. 
there was the Senate, consisting of the former Royal Council, most of whom were governors of provinces (palatines) and governors of main castles (castellans), who would be appointed arbitrarily by the kings and hold life tenure (they could be promoted but not demoted). It was even said that the right to nominate officials and lease royal land was the only prerogative of Polish-Lithuanian monarchs. ${ }^{21}$

In the same year of 1569 , the constitution was passed, establishing a detailed list of seats in the House of Senate and the order of the seats. There were 16 Roman Catholic bishops, 10 "ministers" (4 marshals, 4 chancellors and 2 lords of treasury), 35 palatines (governors of provinces called "palatinates") and 80 castellans (governors of castles). The places for the bishops and ministers were special and we will omit them in further discussion; appointment of the bishops was also subject to Catholic Church regulations; the position of 10 ministers was also special: they occupied the last seats (disproportionate to their real importance), and had special duties (related to the chancellery, treasury and home affairs). ${ }^{22}$

There were up to 130 ordered seats dedicated to (titular) governors of palatinates and castles. The plan of the House of Senate was similar to the current plan of the British House of Commons (see Figure 1): the hall was long, with four rows of seats facing each other and the king's throne in the middle of the short side (the chairs for ministers opposed the royal throne, on the other short side). Every senator knew his place and the relative position of himself and any other senator; it was also obvious for any spectator.

We can find 897 cases of changes of place within the set of governors (palatines and castellans) that were in office from 1569 (until 1795). There were 875 promotions and only 22 demotions (i.e., going down the ladder, changing a seat for one with a higher number, which happened sometimes as a result of two colleagues swapping seats for different reasons, for instance, when some regulations prohibited combining a senatorial seat with another function by the same person or in cases where a seat had been removed after a change in borders). Therefore, the order was fixed and steady.

It was not quite certain what date should be chosen as the end of the period under study. The senate worked until the Third Partition of Poland, i.e., the year 1795. But in 1764, one, and in 1768, six new seats were created. This did not change much, however, as some of their holders were in the senate previously. In 1772 (the First Partition), the borders of Poland-Lithuania were changed, and several provinces fell to Austria, Prussia and Russia, but the seats of the palatines

${ }^{21}$ Ciara, Senatorowie i dygnitarze koronni w drugiej połowie XVII wieku, 11.

${ }^{22} \mathrm{We}$ do not provide detailed sources here because these issues are covered in detail in the sources already mentioned in the preceding paragraphs, for instance in Zielińska, Magnateria polska epoki saskiej, who, e.g., quotes the numbered lists of places in the Senate even if she does not make use of it. 
Figure 1. Plan of the House of Senate, reconstructed by Joachim Lelewel

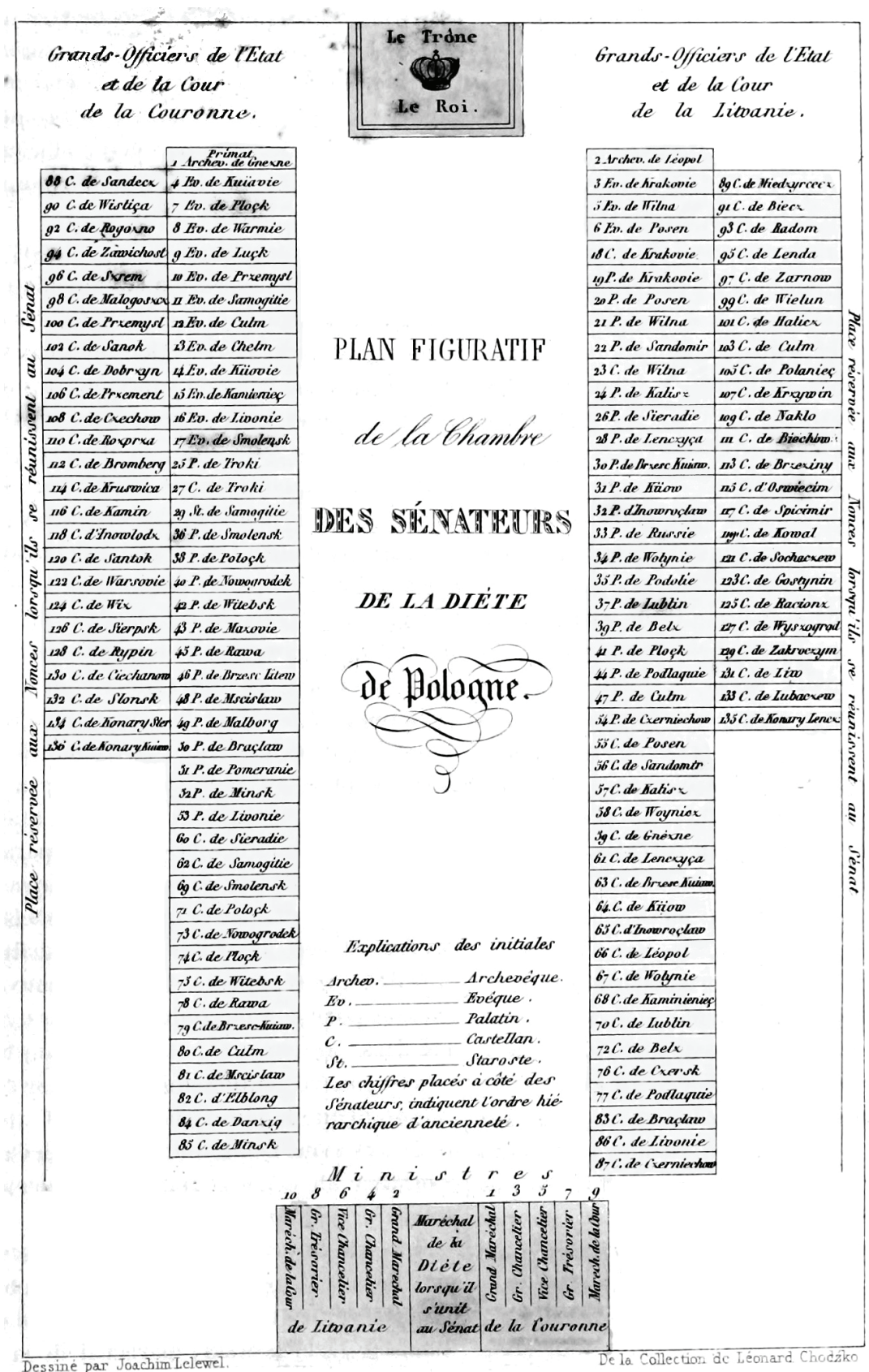

Source: Leonard Chodźko, ed., La Pologne historique, littéraire, monumentale et illustrée, ou scènes historiques [...] (Paris: Bureau Central, 1841), 108. 
and castellans in exile were still occupied. Five further seats were added in 1775. Also in 1775, the political system of Poland-Lithuania changed significantly when the Permanent Council (Concilium Permanens or Rada Nieustajaca) was created; from then onwards, the Council proposed candidatures for the Senate, and the king could only chose one of three candidates. The Council was abolished in 1788 and restored in 1793 when thirteen seats were removed or renamed after the Second Partition. Therefore, if we need precise analysis, the period under study should end in about 1764 (with the election of Stanislaus Augustus), but the general picture of the Senate will be valid until as far as 1795 .

The king had full discretion in appointing senators (at least until 1775). The only limitations were related to their origins: the senator sometimes had to be a terrigena of the province (be a full citizen of the province, i.e., possess a hereditary estate there). Nominations were made in the chancellery of state and registered in the state register (Metryka of the Crown and of Lithuania), so they had to comply with the system (senators could not be removed, nor were double nominations for the same vacancy or for the same person allowed). But otherwise the kings were free to fill the vacancies. The system was in some way similar to the procedure for appointing the members of the Supreme Court in the United States: they are personally, arbitrarily appointed for lifetime tenure by the President of the United States, who in turn is elected in general elections. The main difference was in the fact that the decision of the President of the United States has to be approved by the US Senate while the decision of the Polish king merely had to be formally accepted (published) by the chancellery. ${ }^{23}$

But, as we will see further, there was an intangible power that constrained kings in their decisions. For over 300 years, there was a strong regularity in making senate appointments by subsequent kings which proves that they also needed "advice and consent." 24

As we have said, there is a common assumption that the main actors behind the careers of senators were male dynasties, with the same surname and coatof-arms (heraldic clans). The literature is abundant with discussions as to why some families prospered while others vanished and whether it was related to their fate (having many sons or only having daughters) or their personal talents (or, again, to fate, if the most talented members of the dynasties died young). Such an assumption, however, has never been proved, and there are facts to suggest that

${ }^{23}$ Ciara, Senatorowie i dygnitarze koronni w drugiej połowie XVII wieku, 11.

24 "The President (...) shall nominate, and by and with the Advice and Consent of the Senate, shall appoint Ambassadors, other public Ministers and Consuls, Judges of the Supreme Court, and all other Officers of the United States, whose Appointments are not herein otherwise provided for." Constitution of the United States of America (ARC Identifier 1667751 / MLR Number A1 1: National Archives and Records Administration. Office of the Federal Register, 1787). 
female links were of a similar relevance. We could show, for instance, some important cases of dynasties whose power was inherited down the female line, such as the line from the castellan of Krakow, Andrzej Tęczyński ( $\dagger 1588)$ and his son Jan ( $\dagger 1637)$, through the latter's daughter Izabella ( $\dagger 1667)$, married to Crown Marshal Łukasz Opaliński ( $† 1662)$. Their daughter Zofia Izabela ( $† 1676)$ was married to Crown Marshall Stanisław Herakliusz Lubomirski (†1702); their daughter Elżbieta Lubomirska ( $\$ 1729)$ was married to another castellan of Krakow (Adam Sieniawski, $\uparrow 1726)$ and her daughter Maria Zofia ( $† 1771)$, married to prince August Czartoryski (†1782), was the mother of Adam Kazimierz Czartoryski, probably the most influential man in Polish politics at the end of the 18th century (first cousin to the king and father of Adam Jerzy, unofficial Polish representative at the Vienna Congress in 1814, then Prime Minister during the 1830-31 Polish-Russian war and later the unofficial King of Poland in exile); the latter's palace, in Puławy, was only 6 kilometers from the original Tęczyński estate in Końskowola, the dowry of Anna Konińska, mother of Andrzej Tęczyński, the first in line. ${ }^{25}$ The Polish-Lithuanian legal system did not borrow from Salic Law; from the late Middle Ages, daughters were also their parents' heirs and wives retained their property (the dowry would return to the wife's family if she died childless).

Let us put aside the lines of surnames and focus of the network of connections instead. In several articles by Marek Jerzy Minakowski ${ }^{26}$ there is a discussion of some synthetic measure of social position, the "PSB affinities weight.". ${ }^{27}$ Let us call the measure "Minakowski2016." These weights are published online at Wielcy.pl..$^{28}$ The measure is calculated in the following way: the initial assumption is that every person important for Polish history should have an entry in the Polish Biographical Dictionary, ${ }^{29}$ hereafter: PSB. There are 27,653 entries now (in the

${ }^{25}$ The genealogy was taken from Marek Jerzy Minakowski, "Wielka Genealogia Minakowskiego," 2018, http://wielcy.pl, but can be found in many places; for instance, it can be deduced from biographies of those persons, published in Polski słownik biograficzny, vol. I-LII (Polska Akademia Umiejętności, Instytut Historii Polskiej Akademii Nauk, 1935).

${ }^{26}$ Marek Jerzy Minakowski, "Modelowanie rozkładu kapitału ekonomiczno-społeczno-kulturowego poprzez genealogię masową," Przeszłość Demograficzna Polski 38 (2016): 63-88, https://doi.org/10.18276/pdp.2016.4.38-03; Marek Jerzy Minakowski, "Family Network of Emerging Jewish Intelligentsia (Cracow 1850-1918)," Journal of Historical Network Research 2, no. 1 (December 3, 2018): 53-75, https://doi.org/10.25517/jhnr.v2i1.39; Marek Jerzy Minakowski, "Genealogia Masowa - Metodologia Tworzenia i Publikacji Bazy Danych," in Edytorstwo Wobec Masowości Źródet Najnowszych, vol. 3, Edytorstwo Źródeł XIX i XX Wieku, Teoria i Praktyka (Warszawa: Wydawnictwa Uniwersytetu Warszawskiego, 2018).

${ }^{27}$ In Polish, "waga koligacji PSB." Affinity (in Polish, koligacja) is understood as the relation between two people who are in an extended family, i.e., who are connected by the chain of relations "A is a child or parent or spouse of B." For instance, a cousin of A's spouse's nephew is also one of the affinities of A, even if they are not related, i.e., they do not have any common ancestor.

${ }^{28}$ Minakowski, "Wielka Genealogia Minakowskiego."

${ }^{29}$ Polski stownik biograficzny. 
first 51 volumes, with every volume about $500-800$ pages). The list of entries is based on a consensus among the most eminent Polish academics in history and related sciences). Minakowski's "PSB affinities weight" is the sum of inverse distances from the person in question to the closest 100 people described in the PSB. The distance is understood as the length of the shortest chain of relations from a child, parent or a spouse to the preceding person. Therefore a chain of three means that one is an uncle (the son of a brother of one's mother) or a sister-in-law (a daughter of the father of a spouse) or just a great grandson. ${ }^{30}$ "Inverse" means that if somebody is at a distance of five, we add one fifth for every such person. If somebody had family ties with only four people described in the PSB, two at a distance of 3 , one at a distance of 5 , one at a distance of 7 and one at a distance of 8 , the total weight would be $1 / 3+1 / 3+1 / 5+1 / 7+1 / 8 \approx 1.13$.

Just as in Minakowski's 2017 paper, ${ }^{31}$ in the paradigm of mass genealogy we will use the family network (mass-genealogical network) as a proxy for the social network. Genealogical data are the only social-network data that are consistent and reliable for such an analysis. On the other hand, we are discussing times when arranged marriages were the norm, so we should not expect many accidents here. ${ }^{32}$

With the list of all the members of the Senate and the weight calculated for everybody in the database, we can attribute an average weight to any Senate seat. Next, we can sort the list of seats according to the average affinities weight. Finally, we can order the seats according to the average weight. The order can be understood as the predicted social position of the seat (i.e., of the title of palatine or castellan). Can we guess the order of seats in the House of Senate from this social position (from the average affinities weight of people who occupied them)?

The comparison can be seen in the following chart (see Figure 2): the scatterplot of actual and predicted order of seats in the Senate, accompanied by a linear regression line.

${ }^{30}$ An example of a longer affinity: “the first (male) cousin of A's wife's nephew's brother-inlaw" (in Polish, brat cioteczny szwagra siostrzeńca żony A) is at a distance of 11 from A because he is a son of a son of the father of the father of a son of the father of a wife of a son of a daughter of the mother of a wife. But we can still imagine a situation, e.g., the wedding or funeral of somebody's wife's nephew, where his brother-in-law is also present and is talking about his cousin as his best friend.

${ }^{31}$ Marek Jerzy Minakowski, "Mass Genealogy: Top 1\% of 19-th Century Polish Society as a Single Family Network (PageRank-like Analysis)." (Third European Conference on Social Networks EUSN 2017, Mainz, Germany, 2017), https://www.eusn2017.uni-mainz.de/files/2016/08/ EUSN2017_Booklet_25_09.pdf; Minakowski, "Modelowanie rozkładu kapitału ekonomiczno-społeczno-kulturowego poprzez genealogię masową."

32 Jan Chryzostom Pasek, Pamiętniki Jana Chryzostoma Paska z czasów panowania Jana Kazimierza, Michała Korybuta i Jana III (Petersburg: B.M. Wolff, 1860). 
Figure 2. The order of seats in the Senate predicted by the Minakowski2016 measure (100 inverses of PSB affinities). Calculated from 2,642 positions (1,873 distinct people) occupying a seat in the Senate from 1569 until 1795. Only seats created before 1570 and existing until 1750 are counted. 115 seats are counted. Bishops and ministers are excluded. The line is linear regression with grey standard error area

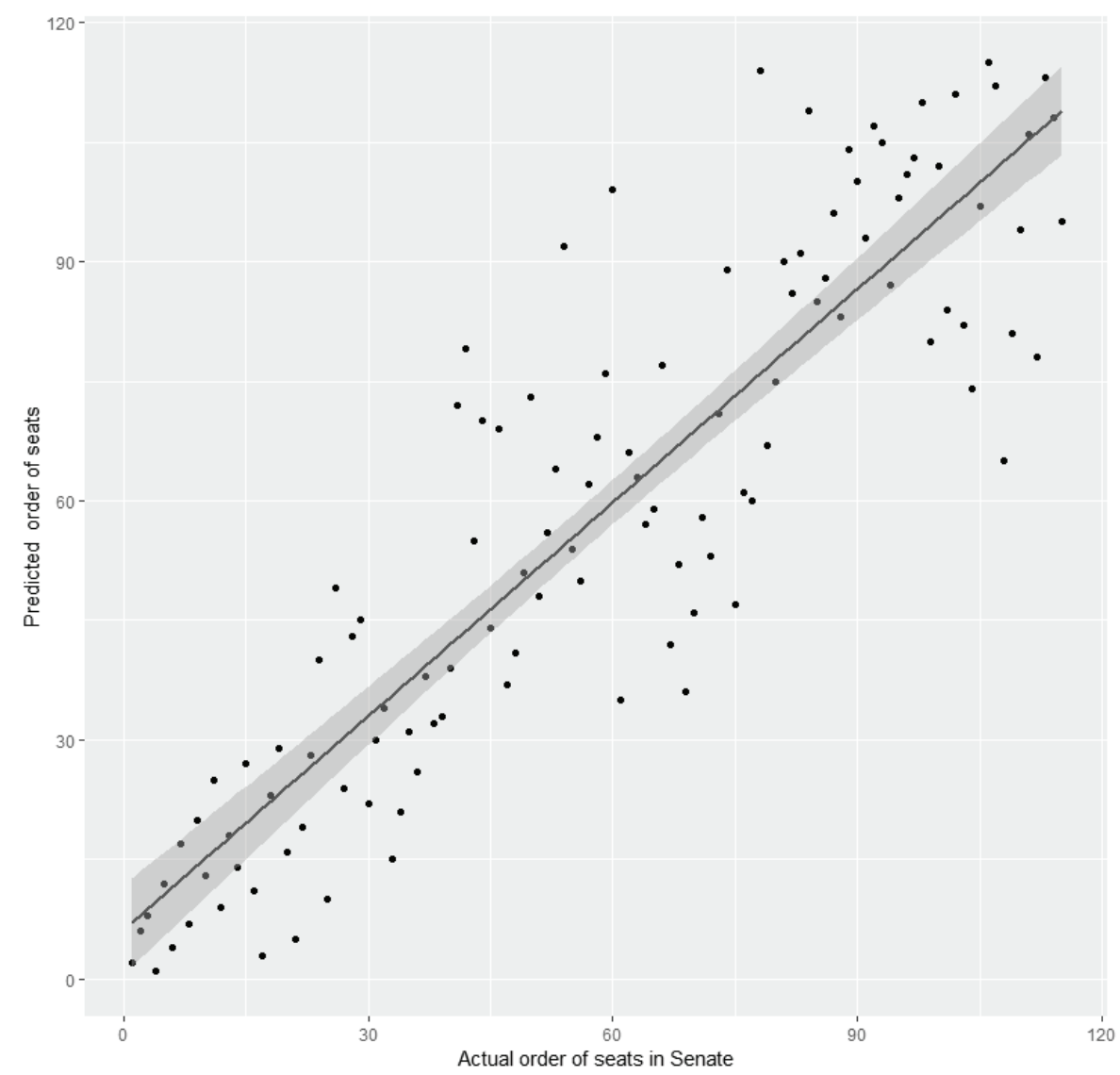

Source: own calculations from data contained in Wielka Genealogia Minakowskiego (online database at https://Wielcy.pl).

The assumptions were: seats created before 1570 and existing until at least 1750; only palatines and castellans (bishops and ministers were excluded). We predicted the order of seats in the following way: for every senator occupying the seat after 1569 , we took his social weight; then we calculated average value of weights for every seat and then we ordered the seats according to the average social weight of the people who occupied them. 
It appeared that the order of seats in the Senate was predicted quite closely. The regression line coefficients are: $0.89303 \mathrm{x}+6.20412$ with $\mathrm{p}$-value $<2 \mathrm{e}-16$. The most interesting result here is that the coefficient of determination $\left(\mathrm{R}^{2}\right)$ is equal to 0.7975 , which means that $80 \%$ of the variance in the order of seats in the Senate can be explained by the social position of the average senator who occupied them.

As we have already seen, the order of seats was fixed in advance, in 1569, and remained steady until at least 1793 (between 1569 and 1764 twelve new seats were created, six of which were abolished by 1680, but the order of the aforementioned 115 old seats was not changed at all). Sigismund II Augustus died in 1572 and in the following period, successive 11 kings were elected. Every king filled vacancies in the Senate according to his own will. Let us see what happened in following periods, all about 100 years:

- from 1468 (the beginning of parliament) to 1569, kings from the Jagiellonian dynasty: Casimir IV, John Albert, Alexander, Sigismund I, Sigismund II,

- 1573-1668 (Henry, Stephen, Sigismund III, Sigismund IV, Jan II Casimir),

- 1669-1763 (Michael, John III, Augustus II, Stanislaus I, Augustus III).

There was also another reign, that of Stanislaus II Augustus (1764-1795), but his reign was full of turmoil, with three consecutive partitions of the state and periods of deep reforms between them; too many factors could have had an impact on the nominations policy, so we will exclude the period.

Table 1. Linear regression of the correlation between actual and predicted order of seats in the Polish-Lithuanian Senate. Prediction according to the Minakowski 2016 measure, averaged separately for every seat in the Senate

\begin{tabular}{ccccccc}
\hline Period & Senators & Nominations & Seats & Slope & Intercept & $\mathrm{R}^{2}$ \\
\hline $1468-1568$ & 514 & 939 & 114 & 0.67 & 19.0 & 0.45 \\
$1573-1668$ & 820 & 1,220 & 123 & 0.80 & 12.6 & 0.64 \\
$1669-1763$ & 818 & 1,063 & 119 & 0.85 & 9.2 & 0.71 \\
\hline
\end{tabular}

Source: own calculations from data contained in Wielka Genealogia Minakowskiego (online database at https://Wielcy.pl).

In the beginning, before the Senate acquired its fully-grown shape (i.e., before 1569), the order of the senators cannot be deduced from the senators' network position. The correlation exists, of course, but is not very strong (see Table 1). On the other hand, the difference between the following two periods is not very big; the correlation grows but it does not suggest any great social or political changes. 
Minakowski ${ }^{33}$ did not prove, however, that his method of calculating the social rank is the best possible. We would need to look closer into the social network. We shall now do that in detail.

\section{The Detailed Analysis}

The whole database of senators comes to 3,517 of them. If the office of palatine or castellan present in the Senate of 1468 existed earlier, we went back as far as the early 14th century, if only we knew the continuous sequence of the office-holders. 2,485 of the senators are mentioned in the PSB - 1875 of them (53\%) have their own entries there (usually describing their whole career path and their family circle). ${ }^{34}$

The families of senators belonged to the elite of Poland and Lithuania and they are described in numerous books; the database Wielcy.p ${ }^{35}$ provides their genealogies.

For every senator we took all the people who had the relation of being a parent, wife or child of a senator.

Next, for any of them we took all the people who were senators or who had entries in the PSB and whose distance from a senator's wife, parent or child was no longer than 8 steps.

Together, we received 11,596,511 such pairs. On the connection side, there were 1,854 people present both in the PSB and in the Senate, 8,567 only in the PSB and 1,340 only in the Senate. In other words, there are 10,421 people described in the PSB and an additional 1,340 senators (without a PSB entry, i.e., less known).

Next, we created a table of all the unique triads "(senator, side, connection)," where:

- side was one of the following: father, mother, wife, child,

- connection was either a senator or a person with a PSB entry.

For every entry we recorded the length of the closest path (how close the senator was to the connection). There were $16,840,646$ such paths.

Next, we chose the closest paths only: if a path from a senator to the connection could be shown through his father and mother and child (which was always

\footnotetext{
${ }^{33}$ Minakowski, "Modelowanie rozkładu kapitału ekonomiczno-społeczno-kulturowego poprzez genealogię masową."

${ }^{34}$ The Polski stownik biograficzny is still unfinished; it covers surnames from A- to Ś- and is just beginning the letter T-; however, only $17 \%$ of all senators active since 1569 have surnames beginning with the letters $\mathrm{T}-\dot{\mathrm{Z}}$, and therefore this should not affect our calculations.

${ }^{35}$ Minakowski, "Wielka Genealogia Minakowskiego."
} 
the case, by the way, as someone's mother is also his father's wife and someone's children are his father's grandchildren etc.), we took only the closest connection.

As a result, we obtained a database of 4,772,462 pairs (senator, connection) where for every pair, the distance (not longer than 9) and the side (father, mother, wife, child) was recorded. 3,073 distinct senators were paired with 11,613 distinct connections. The average senator had 1,553 connections (to other senators or people described in the PSB).

We tried two algorithms for calculating the social network weight, according to its distance: one where every connection was divided by distance, and another where it was divided by the distance's power of two (actually by $2^{n-1}$, where $n$ is the distance between a senator and his connection). The former way is the same that was used in the Minakowski2016 measure with the only difference that Minakowski2016 takes into account only the 100 closest connections, and here we took all the possible connections not longer than 9 .

In the rest of our analysis we will focus on the whole period of 1569-1795. We will focus on senators holding the offices of palatine and castellan (no bishops and not ministers), present in the Senate continuously from at least 1569 until at least 1750 . There were 115 such offices, with 2,018 distinct senators occupying them and 2,799 acts of nomination.

Below is a table comparing different versions of the three algorithms: "Inverse" is the sum of the inverse distances, "Power" is the sum of the inverse powers of 2 and "Minakowski2016" is the measure described earlier, ${ }^{36}$ the sum of the inverse distances to the 100 closest PSB affinities. The column "part" of the algorithms Power and Inverse describes the side from a senator: e.g., "mother" means the part of the family only on the mother's side (people who were closer to the senator's mother than to his father, wife or children). The algorithm Minakowski2016 was calculated for the whole graph, but we read here also (in separate rows) the values for a senator's father, mother, average child and average wife.

The table was sorted by descending coefficient of determination $\left(\mathrm{R}^{2}\right)$, which means that the first rows are the versions of the algorithms which have the best explanatory power (see Table 2).

It appeared that the best explanation is provided by general algorithms, taking the whole family into account. Of the three versions (Inverse, Power and Minakowski 2016), the best explanation is provided by Minakowski2016, which can be called "Inverse 100." We did not test "Power 100" (power, reduced to the closest 100 connections or similar) which could be even better, but this is an issue

\footnotetext{
${ }^{36}$ Minakowski, "Modelowanie rozkładu kapitału ekonomiczno-społeczno-kulturowego poprzez genealogię masową."
} 
that can be discussed in another paper (in the field of algebra or network analysis rather than the social sciences).

Table 2. Comparison of different algorithms for calculating social position of the average senator occupying a given seat in the Polish-Lithuanian Senate. When not specified, the period is $1569-1795$. Ordered by descending coefficient of determination $\left(\mathrm{R}^{2}\right)$

\begin{tabular}{lccccc}
\hline \multicolumn{1}{c}{ Algorithm } & Part & Slope & Intercept & $\mathrm{R}^{2}$ & $\begin{array}{c}\text { Residual } \\
\text { standard } \\
\text { error }\end{array}$ \\
\hline Minakowski 2016 & All & 0.893 & 6.204 & 0.798 & 15.07 \\
Minakowski 2016 & All, from mother & 0.878 & 7.100 & 0.770 & 16.05 \\
Power & All & 0.876 & 7.171 & 0.768 & 16.13 \\
Minakowski 2016 & All, from wife & 0.868 & 7.629 & 0.754 & 16.60 \\
Minakowski 2016 & All, from child & 0.868 & 7.641 & 0.754 & 16.61 \\
Minakowski 2016 & All, from father & 0.867 & 7.716 & 0.752 & 16.69 \\
Inverse & All & 0.856 & 8.358 & 0.733 & 17.32 \\
Minakowski 2016 & All 1669-1768 & 0.847 & 8.865 & 0.718 & 17.79 \\
Power & Wife & 0.836 & 9.537 & 0.698 & 18.40 \\
Minakowski 2016 & All 1569-1668 & 0.805 & 11.286 & 0.649 & 19.85 \\
Power & Child & 0.805 & 11.290 & 0.649 & 19.85 \\
Power & Mother & 0.801 & 11.516 & 0.642 & 20.03 \\
Power & Father & 0.798 & 11.729 & 0.637 & 20.19 \\
Inverse & Wife & 0.785 & 12.461 & 0.617 & 20.74 \\
Inverse & Mother & 0.760 & 13.906 & 0.578 & 21.76 \\
Inverse & Father & 0.742 & 14.947 & 0.551 & 22.44 \\
Inverse & Child & 0.735 & 15.373 & 0.540 & 22.71 \\
Minakowski 2016 & All 1469-1568 & 0.677 & 16.167 & 0.458 & 21.26 \\
\hline
\end{tabular}

Source: own calculations from data contained in Wielka Genealogia Minakowskiego (online database at https://Wielcy.pl).

What is more important here is the comparison of the family part (side). It appears clearly that in all the algorithms, the social network position of the mother and wife/wives of a given senator is more important than the position of his father or the subsequent fate of his children.

This is a very important result. It means that, at least for the elite of the former Polish-Lithuanian Union, covering a vast part of Central and Eastern Europe (currently Poland, Ukraine, Belarus, Lithuania and parts of Latvia), the role of women in the politics of the 16th-18th centuries was much more important than was usually understood. The position of the family of a senator's mother and wife/ wives, on average, had a greater influence on his career than the social position 
of his father. A reduction of the analysis of political careers to male dynasties ("rody") is misleading; it leads to nowhere.

Figure 3. Correlation (linear regression) between average PSB affinities weight (Minakowski 2016 index) and the actual order of seats in the Polish-Lithuanian Senate between 1569 and 1795. $\mathrm{R}^{2}=0.7845$, $\mathrm{p}$-value $<2.2 \mathrm{e}-16$, Residual standard error:

9.672 on 113 degrees of freedom. The line is linear regression with the grey standard error area

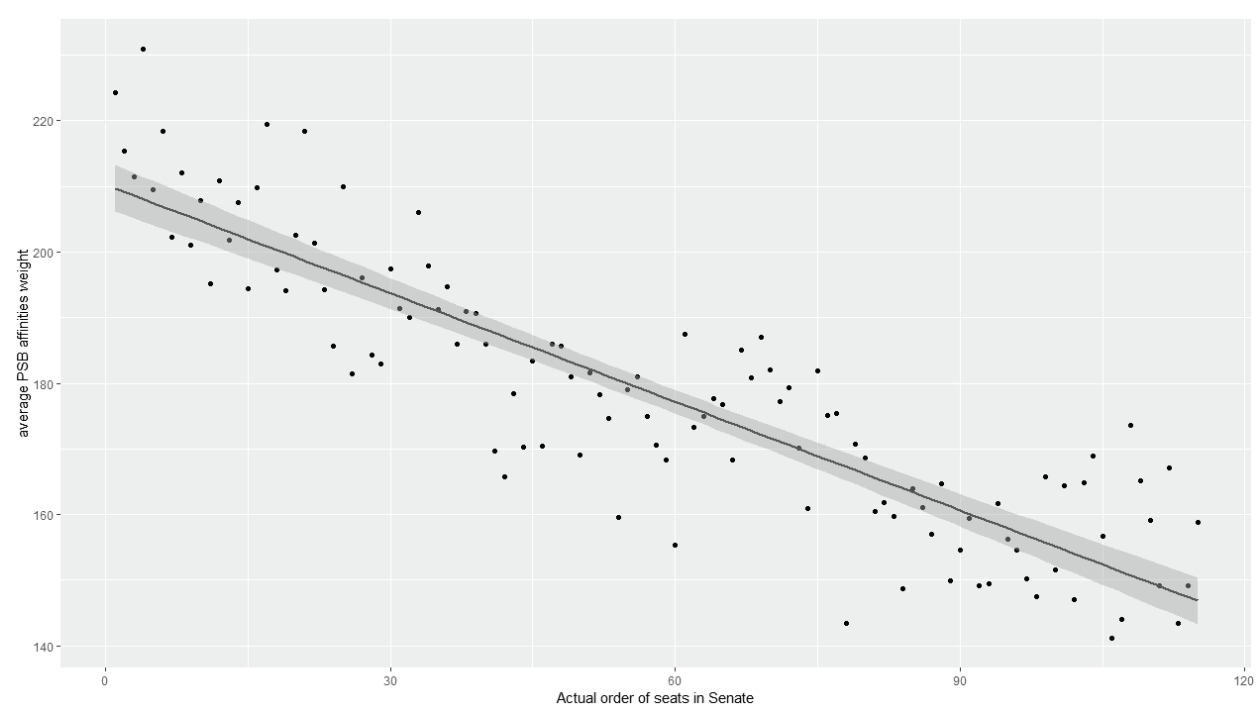

Source: own calculations from data contained in Wielka Genealogia Minakowskiego (online database at https://Wielcy.pl).

All the above outcomes have the value $\mathrm{p}<2 \mathrm{e}-16$. They are statistically significant (see Figure 3).

\section{Conclusions: Connected Network, Not Separate Lines}

Instead of perceiving former society as a set of parallel lines ("lines of succession," "paternal lines"), we should rather consider it a network. The data suggest that the politics of the 16th-18th century Polish-Lithuanian Union was governed by its social network. The network, although not directly visible, had its voice and parliamentary representation, namely the Senate. Subsequent kings unconsciously filled vacancies in the Senate in such a way that it was a representation of the network. The house of Senate was the only house of the Polish-Lithuanian 
three-house Parliament (Sejm) that was not elected - its members were appointed. But in order to rule the country, kings had to appoint them according to the unspoken voice of the network. The royal appointments were not arbitrary - they were representative. The social network was the real force governing the country and even the king could not oppose its will.

In future analyses of the political system of the Polish-Lithuanian commonwealth, historians should pay more attention to the position of politicians on the ladder of offices. It appeared that the formal order of seats in the Senate established in the constitution of 1569 was of real meaning.

It is tempting to analyze the elites of the early modern period by grouping people alphabetically, by surname. But it appears that this is the wrong way, and creates a false impression. Our data show that, at least in the Polish-Lithuanian commonwealth, the career of a politician was connected to the position of his female family (his mother's, wife's) with at least the same force as that of his male line (people sharing the same surname). Historians should never assume that surname groups such as "Zborowscy," "Tęczyńscy," "Tarnowscy," "Czartoryscy," "Radziwiłłowie" etc., were political entities without proving first that, e.g., the brothers were more connected because they had a common mother and common female cousins than because they shared a surname with their great uncle and his male progeny.

It is important to study the dynamics of this network: why some nodes (individuals, families) gained or lost importance; why some people appeared "out of nowhere" and others were "castaways" even if they inherited a good social background. But it is a very difficult task to study in contemporary society: if we could solve the problem, we would know how to turn all our children into geniuses and how to avoid affective disorders. Even contemporary studies on identical twins show that individual success or failure is a mixture of factors. ${ }^{37}$ For sure, it is feasible to gather thousands of individual histories of people (families) from the borders of the social graph ("newcomers" or "castaways") but the author has no idea how to turn a set of histories into statistically significant results; we may thus summarize that the current analysis is focused on "standard" individuals and families, while special cases of unexpected careers or social bankrupts deserve special treatment.

${ }^{37}$ Kenneth S. Kendler et al., "A Longitudinal Twin Study of Personality and Major Depression in Women," Archives of General Psychiatry 50, no. 11 (November 1, 1993): 853-62, https://doi.org/10.1001/archpsyc.1993.01820230023002; Kenneth S. Kendler et al., "Major Depression and Generalized Anxiety Disorder. Same Genes, (Partly) Different Environments?," Archives of General Psychiatry 49, no. 9 (September 1992): 716-22, https://doi.org/10.1001/ archpsyc.1992.01820090044008. 


\section{Conclusions: the Political Role of Women in the Republican Politics of the 16th-18th Centuries}

Professor Ewa Dubas-Urwanowicz recently published a fundamental book on the political machinery of 16th-century Polish-Lithuanian democracy. Titled "History of the House of Zborowski," 38 the book examines the top-level politics of the emerging Polish-Lithuanian Republic as controlled by the Castellan of Krakow, Marcin Zborowski and his sons, with the aid of their nephews and brothers-in-law. From a technical point of view, it is correct, just as Ptolemaic astronomy was also correct in the details when Copernicus was a student. But the Copernican description of the machinery of our Solar System was much simpler, and it ultimately prevailed.

We can thus suppose that their history would be even more interesting if it were called "Elżbieta z Szydłowca Zborowska and her family"; instead of discussing why the Zborowski family lost its power by the end of the 16th century, it could elaborate on her descendants, such as chancellor of the Crown Jerzy Ossoliński (died 1650), palatine of Poznań Krzysztof Opaliński (died 1655), hetman Jan Karol Chodkiewicz (died 1621), chancellor of the Crown Jan Leszczyński (died 1678) and many others, who were her descendants to the same extent as the sons of her son, Marcin Zborowski, castellan of Cracow. Instead of discussing how the sons of Marcin Zborowski were aided by their brothers-in-law, we might focus on the politics of the sons and daughters of Marcin Zborowski or just the descendants of Marcin Zborowski's mother. If we discuss the role of the most famous Polish "outlaw," Samuel Zborowski (whose role in Polish culture is in some ways comparable to the English Robin Hood), we should remember that he was not only a son of the castellan of Krakow, Marcin (as were his brothers), but also a son-in-law of the next castellan of Cracow, Spytek Jordan. His beheading in the courtyard of Cracow castle by the order of a newcomer, Jan Zamoyski, would therefore be even more meaningful.

Of course, this does not mean that the role of women was the same as the role of their sons, brothers and husbands. Women in those times did not hold offices and most did not even write letters. Women were not agents in history in the same way that men were. But we can use physical analogies and claim that forces (gravity, intermolecular forces) are as interesting as bodies (planets, molecules, particles) and studying the role of women in history is even more fruitful because they may be considered as primary force carriers in the system of society. In other words, in the social graph, men were vertices and women were edges. And it is the

${ }^{38}$ Ewa Dubas-Urwanowicz, Mężowie stanu, awanturnicy czy zdrajcy? Dzieje rodu Zborowskich w XVI wieku (Warszawa: DiG, 2018). 
edges that define the shape of the graph, even if single vertices are more visible to the naked eye.

\section{Bibliography}

Bielińska, Maria, Antoni Gąsiorowski, and Jerzy Łojko. Urzędnicy Dawnej Rzeczypospolitej. Spisy. I/1: Urzędnicy Wielkopolscy XII-XV Wieku. Wrocław: Ossolineum, 1985.

Bieniak, Janusz, and Sobiesław Szybkowski. Urzędnicy Dawnej Rzeczypospolitej. Spisy. VI/2: Urzędnicy Kujawscy i Dobrzyńscy XII-XV Wieku. Kórnik: Biblioteka Kórnicka, 2014.

Bieniak, Janusz, and Alicja Szymczakowa. Urzędnicy Dawnej Rzeczypospolitej. Spisy. II/1: Urzędnicy Łęczyccy, Sieradzcy i Wieluńscy XIII-XV Wieku. Wrocław: Ossolineum, 1985.

Bieniaszewski, Adam. Urzędnicy Dawnej Rzeczypospolitej. Spisy. I/2: Urzędnicy Wielkopolscy XVI-XVIII Wieku. Wrocław: Ossolineum, 1987.

Chłapowski, Krzysztof. Elita senatorsko-dygnitarska Korony za czasów Zygmunta III $i$ Wtadystawa IV. Warszawa: Wydawnictwo Sejmowe, 1996.

Chłapowski, Krzysztof, and Alicja Falniowska-Gradowska. Urzędnicy Dawnej Rzeczypospolitej. Spisy. IV/3: Urzędnicy Województwa Sandomierskiego XVI-XVIII Wieku. Kórnik: Biblioteka Kórnicka, 1993.

Chodźko, Leonard, ed. La Pologne historique, littéraire, monumentale et illustrée, ou scènes historiques [...]. Paris: Bureau Central, 1841.

Ciara, Stefan. Senatorowie i dygnitarze koronni w drugiej połowie XVII wieku. Wrocław: Zakład Narodowy im. Ossolińskich, 1990.

Constitution of the United States of America. ARC Identifier 1667751 / MLR Number A1 1: National Archives and Records Administration. Office of the Federal Register, 1787.

Dubas-Urwanowicz, Ewa. Mężowie stanu, awanturnicy czy zdrajcy? Dzieje rodu Zborowskich w XVI wieku. Warszawa: DiG, 2018.

Dubas-Urwanowicz, Ewa, Włodzimierz Jarmolik, Michał Kulecki, and Jerzy Urwanowicz. Urzędnicy Dawnej Rzeczypospolitej. Spisy. VIII: Urzędnicy Podlascy XIVXVIII Wieku. Kórnik: Biblioteka Kórnicka, 1994.

Frost, Robert I. The Making of the Polish-Lithuanian Union, 1385-1569. New York: Oxford University Press, 2015.

Gmiterek, Henryk, and Ryszard Szczygieł. Urzędnicy Dawnej Rzeczypospolitej. Spisy. III/2: Urzędnicy Województwa Betskiego i Ziemi Chetmskiej XIV-XVIII Wieku. Kórnik: Biblioteka Kórnicka, 1992.

Haratym, Andrzej, and Mirosław Nagielski. "Urzędnicy Województwa Rawskiego." In Lauda Ziemi Rawskiej i Województwa Rawskiego 1583-1793, ed. Mirosław Nagielski. Warszawa: Neriton, 2017. 
Janas, Eugeniusz, and Witold Kłaczewski. Urzędnicy Dawnej Rzeczypospolitej. Spisy. III/4: Urzędnicy Województw Kijowskiego i Czernihowskiego XV-XVIII Wieku. Kórnik: Biblioteka Kórnicka, 2002.

Janas, Eugeniusz, Witold Kłaczewski, and Anna Sochacka. Urzędnicy Dawnej Rzeczypospolitej. Spisy. III/3: Urzędnicy Podolscy XIV-XVIII Wieku. Kórnik: Biblioteka Kórnicka, 1998.

Jezierski, Andrzej, and Andrzej Wyczański, eds. Historia Polski w liczbach. I. Państwo. Społeczeństwo. Warszawa: Zakład Wydawnictw Statystycznych, 2003.

Kendler, K. S., M. C. Neale, R. C. Kessler, A. C. Heath, and L. J. Eaves. "Major Depression and Generalized Anxiety Disorder. Same Genes, (Partly) Different Environments?" Archives of General Psychiatry 49, no. 9 (September 1992): 716-22. https:// doi.org/10.1001/archpsyc.1992.01820090044008.

Kendler, Kenneth S., Michael C. Neale, Ronald C. Kessler, Andrew C. Heath, and Lindon J. Eaves. "A Longitudinal Twin Study of Personality and Major Depression in Women." Archives of General Psychiatry 50, no. 11 (November 1, 1993): 853-62. https:// doi.org/10.1001/archpsyc.1993.01820230023002.

Kłaczewski, Witold, and Wacław Urban. Urzędnicy Dawnej Rzeczypospolitej. Spisy. IV/4: Urzędnicy Województwa Lubelskiego XVI-XVIII Wieku. Kórnik: Biblioteka Kórnicka, 1991.

Kurtyka, Janusz, Tomasz Nowakowski, Franciszek Sikora, Anna Sochacka, Piotr K. Wojciechowski, and Bożena Wyrozumska. Urzędnicy Dawnej Rzeczypospolitej. Spisy. IV/1: Urzędnicy Małopolscy XII-XV Wieku. Wrocław: Ossolineum, 1990.

Lulewicz, Henryk, Andrzej Rachuba, and Przemysław P. Romaniuk. Urzędnicy Wielkiego Księstwa Litewskiego I: Województwo Wileńskie. Warszawa: DiG, 2004.

____ Urzędnicy Wielkiego Księstwa Litewskiego IV: Ziema Smolenska i Województwo Smoleńskie. Warszawa: DiG, 2003.

Lulewicz, Henryk, Andrzej Rachuba, Przemysław P. Romaniuk, and Andrzej Haratym. Urzędnicy Wielkiego Księstwa Litewskiego II: Województwo Trockie. Warszawa: DiG, 2006.

___ Urzędnicy Wielkiego Księstwa Litewskiego III: Księstwo Żmudzkie. Warszawa: DiG, 2015.

McLean, Paul D. "Widening Access While Tightening Control: Office-Holding, Marriages, and Elite Consolidation in Early Modern Poland." Theory and Society 33, no. 2 (2004): 167-212.

Mikulski, Krzysztof. Urzędnicy Dawnej Rzeczypospolitej. Spisy. V/2: Urzędnicy Prus Królewskich XV-XVIII Wieku. Wrocław: Ossolineum, 1990.

Mikulski, Krzysztof, and Andrzej Rachuba. Urzędnicy Dawnej Rzeczypospolitej. Spisy. IX: Urzędnicy Inflanccy XVI-XVIII Wieku. Kórnik: Biblioteka Kórnicka, 1994.

Mikulski, Krzysztof, and Wojciech Stanek. Urzędnicy Dawnej Rzeczypospolitej. Spisy. VI/2: Urzędnicy Kujawscy i Dobrzyńscy XVI-XVIII Wieku. Kórnik: Biblioteka Kórnicka, 1990. 
Minakowski, Marek Jerzy. "Family Network of Emerging Jewish Intelligentsia (Cracow 1850-1918)." Journal of Historical Network Research 2, no. 1 (December 3, 2018): 53-75. https://doi.org/10.25517/jhnr.v2i1.39.

___ "Genealogia Masowa - Metodologia Tworzenia i Publikacji Bazy Danych." In Edytorstwo Wobec Masowości Źródel Najnowszych, Vol. 3. Edytorstwo Źródeł XIX i XX Wieku, Teoria i Praktyka. Warszawa: Wydawnictwa Uniwersytetu Warszawskiego, 2018.

___ . "Mass Genealogy: Top 1\% of 19th-Century Polish Society as a Single Family Network (PageRank-like Analysis).” Mainz, Germany, 2017. https://www.eusn2017. uni-mainz.de/files/2016/08/EUSN2017_Booklet_25_09.pdf.

. "Modelowanie rozkładu kapitału ekonomiczno-społeczno-kulturowego poprzez genealogię masową.” Przeszłość Demograficzna Polski 38 (2016): 63-88. https://doi. org/10.18276/pdp.2016.4.38-03.

____. "Wielka Genealogia Minakowskiego," 2018. http://wielcy.pl/.

Opaliński, Edward. Elita władzy w województwach poznańskim i kaliskim za Zygmunta III. Poznań: Wydawn. Poznańskie, 1981.

___ Rodziny wielkosenatorskie w Wielkopolsce, na Kujawach i na Mazowszu za Zygmunta III: podstawy karier. Warszawa: Wydawnictwo DiG, 2007.

Opaliński, Edward, and Hanka Żerek-Kleszcz. Urzędnicy Dawnej Rzeczypospolitej. Spisy. II/2: Urzędnicy Województw Łęczyckiego i Sieradzkiego XVI-XVIII Wieku. Kórnik: Biblioteka Kórnicka, 1993.

Pasek, Jan Chryzostom. Pamiętniki Jana Chryzostoma Paska z czasów panowania Jana Kazimierza, Michała Korybuta i Jana III. Petersburg: B. M. Wolff, 1860.

Polski słownik biograficzny. Vol. I-LII. Polska Akademia Umiejętności, Instytut Historii Polskiej Akademii Nauk, 1935.

Przyboś, Kazimierz. Urzędnicy Dawnej Rzeczypospolitej. Spisy. III/1: Urzędnicy Województwa Ruskiego XIV-XVIII Wieku. Wrocław: Ossolineum, 1987.

Wolff, Józef. Senatorowie i Dygnitarze Wielkiego Księstwa Litewskiego 1386-1795. Kraków: Drukarnia W.L. Anczyca, 1885.

Wolski, Marian. Urzędnicy Dawnej Rzeczypospolitej. Spisy. III/5: Urzędnicy Wotyńscy XIV-XVIII Wieku. Kórnik: Biblioteka Kórnicka, 2007.

Zielińska, Teresa. Magnateria polska epoki saskiej: funkcje urzędów i królewszczyzn w procesie przeobrażeń warstwy społecznej. Wrocław: Ossolineum, 1977.

Zieliński, Ryszard. “Chronologia Senatorów Płockich.” Notatki Płockie 3, no. 8 (1958): 36-44.

____ "Senatorowie Płoccy: Dokończenie.” Notatki Płockie 5, no. 2-16 (1960): 24-30.

Żychliński, Teodor. “Biskupi, Senatorowie i Dygnitarze Polscy. I. Biskupi.” Złota Księga Szlachty Polskiej XV (1893): 167-214.

____ "Biskupi, Senatorowie i Dygnitarze Polscy. II. Senatorowie Świeccy. A. Kasztelanowie.” Złota Księga Szlachty Polskiej XVI (1894): 165-280. 
. "Biskupi, Senatorowie i Dygnitarze Polscy. II. Senatorowie Świeccy. B. Wojewodowie.” Złota Księga Szlachty Polskiej XVII (1895): 191-249.

___ _Biskupi, Senatorowie i Dygnitarze Polscy. III. Ministrowie." Złota Księga Szlachty Polskiej XVII (1895): 249-77.

\section{House of Networks: the Polish-Lithuanian Senate (1569-1795) as Parliamentary Representation of the National Social Network (of Women?)}

\section{Summary}

The article presents evidence that social networks can be considered a real subject (actor) of the internal policy of a democratic state, with representation in the form of the upper house of parliament.

The political system of the Republic of Poland and Lithuania from 1569 to at least 1775 assumed that power belonged to the 3-chamber parliament, consisting of: a king (elected for life in general elections), a House of Representatives (elected every two years in local elections) and a Senate (about 140 senators nominated by subsequent kings). It was assumed that the king's nominations to the Senate were arbitrary, but it transpired that they were dictated by the position of the nominees in a nationwide family network (we have already managed to locate $90 \%$ of all senators within this network in the given period).

We collected data on the family connections of the Polish elite from all available sources so as to reconstruct one large graph in the paradigm of mass genealogy. It allowed us to measure the social position of all the senators and their relatives and show this as numerical values. The algorithm for determining the value of social position was used in several variants so that the accuracy of the predictions of the different algorithms can be compared. The hypothesis of the influence of the social network on senatorial appointments was formulated as the supposition that it is possible to predict the formal (constitutional) hierarchy of places in the Senate based on a knowledge of the family connections within society. Confirmation that there is a statistically significant correlation would mean that such an effect actually existed and finding that one of the algorithms gives a better prediction would mean that the factors used in it are more significant.

Such dependencies were confirmed. Nominations in the long term (ten successive royal terms) show that the official hierarchy in the Senate can be deduced from the shape of the social (family) network. At the same time, it transpired that compared to the traditional description of the elites as a set of families connected by a common surname (inherited down the male line), better (or at least equally good) results are obtained by analyzing the female lines - the position of the wives and mothers of the nominees. Although women did not sit in the Senate, their role in shaping it (active or passive) was at least 
as large as that of the men, so one cannot abstract from this role, and give a description of the country's political elite as if it consisted of a set of patrilineal dynasties - instead, it should be described as a graph composed equally of women and men, because only such a description will be adequate.

\section{Izba Sieci. Polsko-litewski senat (1569-1795) jako reprezentacja parlamentarna ogólnokrajowej (kobiecej?) sieci społecznej}

\section{Streszczenie}

Artykuł przedstawia dowody na to, że sieć społeczna może być traktowana jako rzeczywisty podmiot (aktor) polityki wewnętrznej demokratycznego państwa, posiadający swoją reprezentację w postaci izby wyższej parlamentu.

Ustrój Rzeczypospolitej Polski i Litwy od roku 1569 do co najmniej 1775 zakładał, że władza należy do 3-izbowego parlamentu, na który się składają: król (wybierany dożywotnio w wyborach powszechnych), Izba Poselska (wybierana powszechnie co dwa lata w wyborach lokalnych, sejmikach) i Senat (około 140 senatorów nominowanych przez kolejnych królów). Przyjmowano dotąd, że decyzje nominacyjne króla były arbitralne, tymczasem okazało się, że były one dyktowane przez pozycję nominatów w ogólnokrajowej sieci powiązań rodzinnych (w której to sieci udało się umiejscowić około $90 \%$ wszystkich senatorów w badanym okresie).

Zebrano dane o powiązaniach rodzinnych elit Rzeczypospolitej z wszelkich dostępnych źródeł - tak by zrekonstruować jeden wielki graf, w paradygmacie genealogii masowej. Pozwoliło to zmierzyć pozycję społeczną wszystkich senatorów i członków ich rodzin, i przedstawić ją jako liczbę. Algorytm wyznaczania wartości pozycji społecznej wykorzystano w kilku wariantach - tak, by można było porównać trafność przewidywań różnych algorytmów. Hipoteza wpływu sieci społecznej na nominacje senatorskie polegała na przypuszczeniu, że da się przewidzieć formalną (konstytucyjną) hierarchię miejsc w senacie na podstawie znajomości powiązań rodzinnych wewnątrz społeczeństwa. Potwierdzenie, że istnieje statystycznie istotna korelacja, oznaczałoby że wpływ taki występował faktycznie, zaś ustalenie że któryś z algorytmów daje lepszą predykcję oznaczałoby, że czynniki w nim wykorzystane są bardziej istotne.

Udało się potwierdzić takie zależności. Nominacje w długim okresie (dziesięciu kolejnych kadencji królewskich) pokazują, że urzędową hierarchię w senacie da się wydedukować z kształtu sieci społecznej (rodzinnej). Jednocześnie okazało się, że w porównaniu do tradycyjnego opisu elit jako zbioru rodzin połączonych wspólnym nazwiskiem (dziedziczonym w linii męskiej), lepsze (lub co najmniej tak samo dobre) wyniki uzyskamy, analizując linie żeńskie - pozycję żon i matek nominatów. Choć kobiety same w senacie nie zasiadały, to ich rola w jego kształtowaniu (czynna lub bierna) była co 
najmniej tak duża, jak mężczyzn, nie wolno więc abstrahować od tej roli i w opisie elity politycznej kraju oddawać ją tak, jakby składała się ze zbioru patrylinearnych dynastii zamiast tego należy ją opisywać jak graf złożony po równi z kobiet i mężczyzn, bo tylko taki opis będzie adekwatny. 